\title{
The Influence of Holothuriaatra(Echinodermata: Holothuroidea)on Organic Matter Assimilation, Ammonification and Nitrification Rate of Sediment.Hurghada,Red Sea, Egypt.
}

\author{
E.E. Shabana ${ }^{1}$,W.M. El Kazzaz ${ }^{2}$, M.R. Dar ${ }^{3}$, A. Dewedar ${ }^{2}$ \\ ${ }^{1}$ Egyptian Environmental Affairs Agency, Hurghada Branch, Red Sea, Egypt. \\ ${ }^{2}$ Botany Department, Faculty of Science, Suez Canal University, Egypt. \\ ${ }^{3}$ National Institute of Oceanography and Fisheries, Hurghada, Red Sea, Egypt.
}

\begin{abstract}
This study was undertaken to investigate the effect of sea-cucumber (Holothuriaatra) population density on sea bottom sediment; redox potential, Total organic matter (TOM) assimilation, ammonification and nitrification activity. In protected aquaculture ponds at National Institute of Oceanography and Fisheries (NIOF), Four treatments of high population density (108 individuals/HPDP of $30 \mathrm{~m}^{2}$ ), mediumpopulation density (54 individuals/MPDP of $30 \mathrm{~m}^{2}$ ), low population density (18 individuals/LPDP of $30 \mathrm{~m}^{2}$ ) and reference (RP; Empty ofH.atra). Intestinal (Foregut and hindgut) of $H$. atra and ambient sediment samples were used. The data showed that presence of Holothuriaatra increase the Redox Potential of sediment and kept its characteristics in the oxidized form which enhanced the biological activities. The TOM decreased by $16.04 \%$ (22.32\% to $6.28 \%) ; 5.34 \%(10.54 \%$ to $5.2 \%) ; 3.02 \%(8.02 \%$ to $5.0 \%)$ and $3.61 \%(8.35 \%$ to $4.74 \%)$ in HPDP, MPDP, LPDP and reference pond respectively. The maximum monthly mean of ammonia was $6.93 \mu \mathrm{gg}^{-1}$ in HPDP and the lowest mean was $0.09 \mu \mathrm{g} \mathrm{g}^{-1}$ in recorded in LPDP. Ammonia and nitrate concentrations in the ponds of $H$. atrawereslightly reduced compared with the RP while nitrite concentration followed different pattern. The highest count of ammonifying,ammonium oxidizing and nitrite oxidizing bacteria were $1100 \mathrm{MPN} / \mathrm{g}, 460 \mathrm{MPN} / \mathrm{g}$ and64 MPN/g recorded in foregut contents.Meanwhile the lowest count was31.5 MPN/g, 20 MPN/g and 6.75 in RP, hindgut contents and LPDP respectively. The highest Ammonification and nitrification activity were $36.69 \mu \mathrm{g} / \mathrm{g} / \mathrm{h}$ and $1.19 \mu \mathrm{g} / \mathrm{g} / \mathrm{hrecorded}$ in HPDP meanwhile, the lowest values were $7.38 \mu \mathrm{g} / \mathrm{g} / \mathrm{h}$ and $0.07 \mu \mathrm{g} / \mathrm{g} / \mathrm{h}$ in RP. Ammonification rate and nitrification rate in foregut were higher than in hindgut contents and the ambient sediment. Data analysis showed ammonia-N; nitrate- $\mathrm{N}$ and nitrite-N concentration varied non significantly with $H$. atra population density $(\mathrm{p}>0.05)$ while a highly significant effect recorded with oxidation reduction potential $(\mathrm{Eh})$ and Nitrification activity $(\mathrm{p}<0.01)$ and significant effect on TOM matter and Ammonification rate $(\mathrm{p}<0.05)$. This study emphasizes the ecological role of the most dominant holothurians species, $H$. atra, especially in relation to organic matter assimilation, through its associated bacteria that enhance ammonification and nitrification processes in sediment.
\end{abstract}

Keywords: Holothuriaatra, Total organic matter, Ammonification rate, Nitrification rate.

Corresponding Author:E.E.Shabana. E-mail: miarmetwaly@gmail.com. Tel: +201010397020

\section{1- Introduction}


The holothurians, or sea cucumbers, include a class, Holothuroidea, of some 900 members within the invertebrate phylum Echinodermata (Barnes, 1987).About 80 species of sea cucumber belonging to 22 generarecorded in the Red Sea (Vine, 1986).Holothurians and other sedimentfeeders are key components of a benthic recycling system that may have some similarity to the planktonic microbial loop (Uthicke, 2001a).Holothurians are also believed to play a significant role in nutrient cycling and sediment modification in shallow-water habitats (Amon and Hemdl, 1991; Hanafy, 2011). Holothurians are common inhabitants of sheltered marine shallow-water substrates;obtain food by the ingestion of marine sediment, or by filtration of sea water. Depositfeeding holothurians are well-known members of many deep benthic communities (Laubier and Sibuet, 1979; Menzieset al., 1973; Graham and Ballaglene, 2004)where they are assumed to mix up the deep sea mud on a large range (Heezen and Hollister, 1971). Sediment ingested by deposit feeding holothuroids is of low nutrient value. The low richness of organic matter forces the deposit feeders to ingest large amounts of sediment to obtain their required energy (Santos et al., 1994).

Holothurians fecal pellets contribute to the detritus pool in coastal ecosystems. Pellets are deposited normally in unsystematicmanner, forming fecal mounds of variable size and organic matter content, often richer than the neighboring sediment (Sloan and von Bodungen, 1980). Organic matter from decaying fecal pellets can be re-suspended by waves, currents and biota and will influence the relative amounts of organic carbon (Hopkinson, 1985). Re-suspension seems to favor repositioning of particulate material rather than dissolved nutrients (Wainwright, 1990).

The use of direct count techniques demonstrated higher numbers of bacteria in the holothurian intestinal tract than in the neighboring sediment (Deming and Colwell, 1982). On the basis of these findings, the presence of an active commensal gut flora metabolizing organic matter ingested by the holothurian was suggested (Deming and Colwell, 1982). Other reports (Phillips, 1984; Barlocher and Kendrick, 1978) have suggested that gut bacteria may have an important role in the supply of particular necessary amino acids to the holothurian, in the same manner that rumen microbes supply some essential nutrients to their hosts (Purser, 1970). On the other hand Dilution plating of samples indicated that numbers of culturable bacteria were greater in the hindgut than in the foregut, but in both cases less than that found in the surrounding sediment (Ward-Raineyet al., 1996).

Holothuriaatra is one of the most common and widest ranging tropical, coral reef sea cucumbers in the world (Skillingset al., 2011). Holothuriaatra is the most abundant and frequent holothurian in all countries within the region (common name: black lollyfish), and therefore one of the most studied species despite its low commercial value (Conand, 1996; Jaquemetet al., 1999; Uthickeet al., 2001b;Dhinakaran and Liptonb, 2014;Conand and Mangion, 2002; Conand, 2004; Taddei, 2006).

The nutrition of $H$. atra has been studied, as the species is a major component of the softbottom reef communities and mudflats (Taddei, 2006; Ashaet al., 2015); Conand and Mangion, 2002; Conand, 2008, Purcell et al., 2009). The nutrition of the two dominant species, Holothuriaatra and H. leucospilota, has first been studied at two sites, one eutrophicated and one oligotrophic (Mangion et al., 2004). Gut content analysis showed that the organic matter ingested from the sediment was used with 10 percent efficiency for both species (Mangion et al., 2004). The carbon: nitrogen ratio decreased along the gut showing organic matter degradation. This shows the ability of these holothurians to break down the organic matter from the sediment and to make it easily available for other organisms (Mangion et al., 2004).

During the last decade, fishing of sea cucumber has appeared as major added threats to Egyptian reefs of the Red Sea. After the reduction of sea cucumber fisheries in other parts of the 
world (kinch, 2002).By 2000, the sea cucumber fisheries in Egypt had increased greatly as a result of high demand for beche-demer and the high prices paid for it. Between 2002 and 2004, extensive fishing of sea cucumber caused a serious depletion in the natural stocks where commercial species disappeared completely from many reefs (Hanafy, 2011). Lawrence et al., (2004), provided detailed density estimates for different areas in Egypt. Holothuriaatra was by far the most abundant followed by Actinopygamauritiana. A second survey conducted four years following the official fishing ban, has shown that there was some evidence of the return of some commercial species, but no evidence of stock recovery (Ahmed and Lawrence, 2007). This work is designed to investigate the impact of sea cucumber removal, represented by Holothuriaatra, on physico-chemical characteristics, specific bacterial content and the rate of ammonification and nitrification processes of inthe animal gut contents and the sea floor sediment.

\section{2-Materials and methods}

\subsection{Experimental site and design}

A preliminary survey had been made to select aappropriatesite, characterized with high density of $H$. atra, near to Hurghada city and easily accessible at any time without obstacles. The other selected site was to establish aquaculture ponds to study the effect of H.atraon sediment features. As a result of survey we found that the best location to collect $H$. atra, identified within

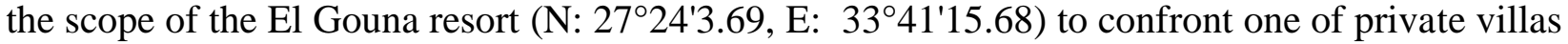
as shown in figure (1); it had not been subjected to overfishing until the completion of the study (El Gouna site-A). The aquaculture pond (N: $27^{\circ} 17^{\prime} 6.21$, E: $\left.33^{\circ} 46^{\prime} 23.02\right)$ of (NIOF) was selected and modified shown in figure (2). The pond was $10 \mathrm{~m} \times 12 \mathrm{~m}$, divided into four sections by using green nets supported by metal stands and embedded in the pond sediment to $20 \mathrm{~cm}$ depth to avoid the animal escaping from one section to the neighboring one. Each of the sub-ponds had the dimensions $5 \mathrm{~m} \times 6 \mathrm{~m}$, the water get into and get out of the ponds following the high and low tide of the sea through fine crevices in the pond walls. About 200 animals collected and distributed into the pre-prepared sub-ponds. In the first section (HPDP: 108 animals) of H.atra was allocated while in the second 54 animals allocated to represent the MPDP and in the third 18 animals was allocated to represent LPDP, while the fourth section of the pond was left as a reference or control pond.

\subsection{SEDIMENT SAMPLING AND ANALYSIS FOR PHYSICO-CHEMICAL PARAMETERS OF SEDIMENT.}

Sediment samples were collected monthly by using a transparent cylindrical corer of 4.5 $\mathrm{cm}$ diameter and $50 \mathrm{~cm}$ length. The samples were collected in a $500 \mathrm{~g}$ sterilized plastic bags. Three cores with $10 \mathrm{~cm}$ heights ambient sediment were collected randomly from each of the population desity ponds and reference pond and placed into labeled plastic bags. Physicochemical parameters were analyzed for each sample. At the time of sampling, Oxidation Reduction potential (Eh)was measured by using a digital pH meter (Hanne III 9024C). Determination of weight of sediment organic matter (and thereafter percent organic matter-POM) of the digestive tract contents and the ambient sediments were determined by thesequential loss on ignition (Dean, 1974). Ammonia was measured by using the method of Steam Distillation with magnesium oxide according to the procedure described by (Bremner and Keeney, 1965). Oxidized nitrogen (nitrate + nitrite) was determined according to the method of Steam Distillation with $\mathrm{MgO}$ and Devarda's alloy after removal of ammonia-nitrogen by steam distillation method ( Brenmer and Keeney, 1965). Nitrite was measured colorimetry based on the Griess-Ilosvy Method which reported by Barnes and Folkard(1951)and Bremner(1965). 


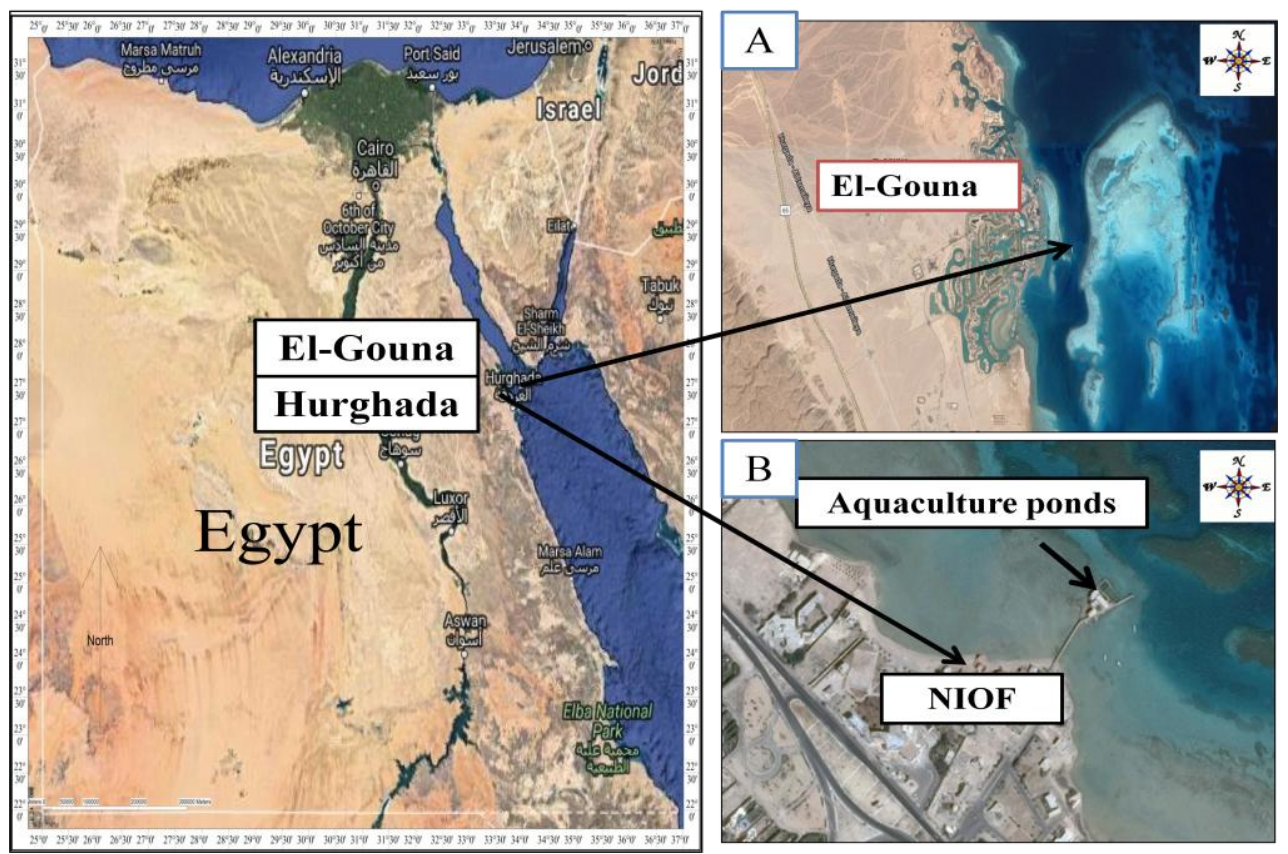

Figure 1: location map of Elgouna Resort (A: Sea cucumber collection site) and NIOF aquaculture pond (B: protected experiment), the site position in relation shoreline. Hurghada, Egypt.

\subsection{GUT CONTENTSAND AMBIENT SEDIMENT SAMPLINGANALYSIS FORBACTERIAL COUNT AND ACTIVITY.}

\subsection{SPECIMEN COLLECTION}

Three actively feeding H.atrawere collected from different ponds and a replacement with the same numbers were done to keep the density. The holothurians' were placed on a sterilized surface. The dissection was carried out within $2 \mathrm{~h}$ of collection, under aseptic conditions. The animal's body wall was cut away to expose the intestine, which was removed to a sterile container. An incision was made at each end of the gut, and samples of gut content were removed from the fore and hindgut areas. Ambient sediment samples also collected.

\subsubsection{ENUMERATION OF AMMONIFYING AND NITRIFYING BACTERIA}

According to Belser and Mays (1982) and Alexander (1982) Most Probable Number MPN technique used for Enumeration of Ammonifying and Nitrifying bacteria in sediment ponds, foregut contents and hind gut contents of Holothuriaatra, by MPN.

\subsubsection{Determination of Ammonification and nitrification Activity.}

Potential ammonification rates were measured by following the conversion of L-arginine to ammonium (Alef and Kleiner, 1986; Nancy et al., 1995). Nitrification activity was measured according to the procedure reported by (Schmidt and Belser, 1982; Groffman, 1987).

\section{4- RESUlTS}

The highest $E h$ value was $223 \mathrm{mV}$ recorded in January at the MPDP while the minimum value $168 \mathrm{mV}$ was recorded in May at RP. In the HPDP the $E h$ was increased from $207 \mathrm{mV}$ in the 
beginning of the experiment to $221 \mathrm{mV}$ at the end of the experiment. Slight changes recorded in $E h$ value in both MPDP and LPDP. In general, the bottom sediments of the controlled experiment ponds preserve their characteristics in the oxidized form which enhanced the biological activities (Table 1; Figure2).The presence of sea cucumbers $H$. atra had a highly significant effect $(\mathrm{p}<0.001)$ on the Eh values in the sediment over the 6 months period of the experiment.

The TOM decreased by $16.04 \%$ (22.32\% to $6.28 \%) ; 5.34 \%(10.54 \%$ to $5.2 \%) ; 3.02 \%$ $(8.02 \%$ to $5.0 \%)$ and $3.61 \%(8.35 \%$ to $4.74 \%)$ in HPDP, MPDP, LPDP and RP, respectively. The highest TOM $(23.32 \%)$ was recorded in the HPDP in December while the minimum value was $4.74 \%$ at the RP in April (Figure 3). H. atra causes significant decreasing in TOM contents in sediment from $22.32 \%$ to $6.28 \%$, from $10.54 \%$ to $5.2 \%$, from $8.02 \%$ to $5.0 \%$ and from $8.35 \%$ to 4.74\% in HPDP, MPDP, LPDP and RP respectively. TOM\% in the gut content was fluctuated from $6.93 \%$ to $26.57 \%$. The averages of TOM in gut contents recorded higher percentages than the ambient sediments in December, April and May (Table 1; Figure4).

Table 1: Overall means of Eh, $(\mathrm{mV})$, TOM $(\%)$, ammonia- $\mathrm{N}(\mu \mathrm{g} / \mathrm{g})$, nitrate $\mathrm{N}(\mu \mathrm{g} / \mathrm{g})$ andnitrite$\mathrm{N}(\mu \mathrm{g} / \mathrm{g})$; in the sediment of different ponds populated with $H$. atra over experimental period of 6 months

\begin{tabular}{lccccc}
\hline Station & $\begin{array}{c}\text { Eh } \\
(\mathbf{m V})\end{array}$ & $\begin{array}{c}\text { TOM } \\
(\boldsymbol{\%})\end{array}$ & $\begin{array}{c}\text { Ammonia-N } \\
(\boldsymbol{\mu g} / \mathbf{g})\end{array}$ & $\begin{array}{c}\text { Nitrate-N } \\
(\boldsymbol{\mu g} / \mathbf{g})\end{array}$ & $\begin{array}{c}\text { Nitrite-N } \\
(\boldsymbol{\mu g} / \mathbf{g})\end{array}$ \\
\hline HPDP & 217.17 & 12.24 & 3.06 & 4.38 & 0.10 \\
MPDP & 215.83 & 7.49 & 2.82 & 4.09 & 0.10 \\
LPDP & 203.67 & 6.87 & 2.67 & 3.59 & 0.10 \\
R.pond & 182.67 & 6.35 & 3.11 & 3.71 & 0.14 \\
\hline
\end{tabular}

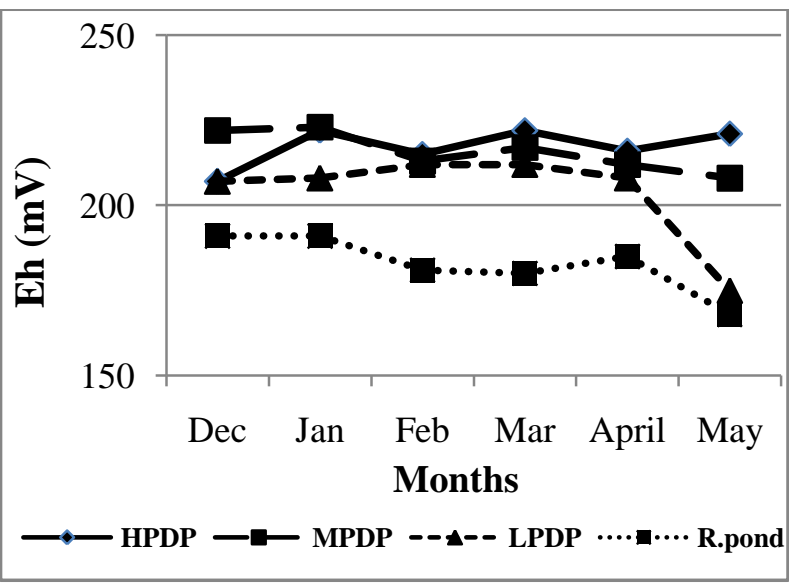

Figure 2: Average of Eh (mV) measured monthly in different population density ponds of $\mathrm{H}$. atra (i.e. $\mathrm{HPDP}=108, \mathrm{MPDP}=54, \mathrm{LPDP}=18$ and $\mathrm{RP}=$ zero individuals /pond) over 6 months.

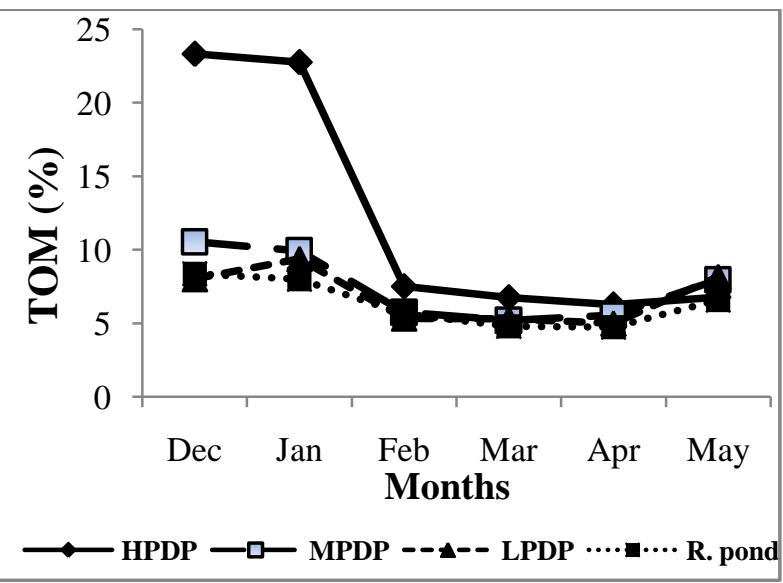

Figure 3: Average of TOM (\%) measured monthly in different population density ponds of $\mathrm{H}$. atra (i.e. HPDP $=108, \mathrm{MPDP}=54, \mathrm{LPDP}=18$ and $\mathrm{RP}=$ zero individuals /pond) over 6 months. 


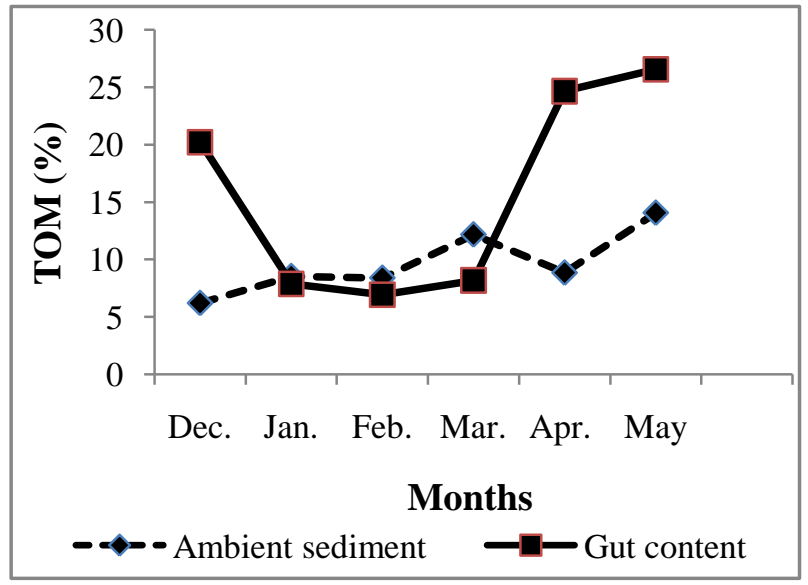

Figure 4: Average monthly variation ofTOM (\%) in gut contents of $H$. atra and ambient sediment at El Gouna Resort, Hurghada, Egypt.

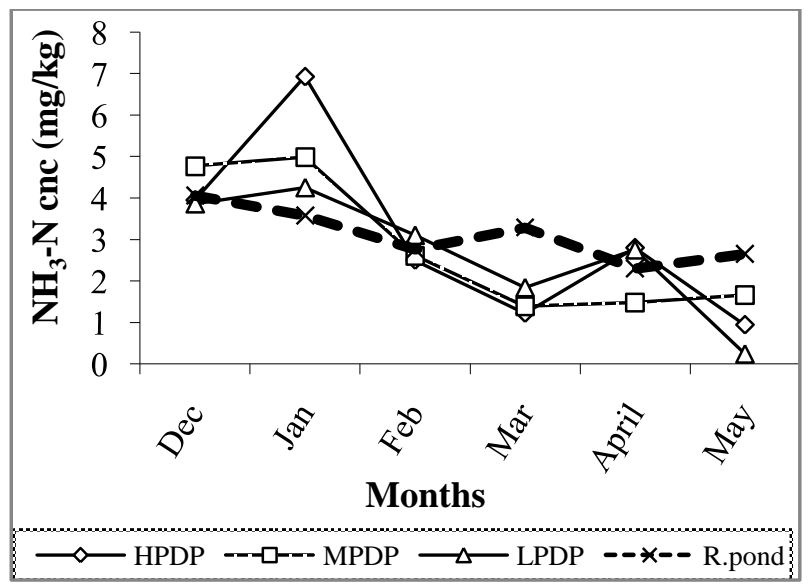

Figure 5: Average of Ammonia- $\mathrm{N}$ measured monthly in different population density ponds of $H$. atra (i.e. $\mathrm{HPDP}=108, \mathrm{MPDP}=54, \mathrm{LPDP}=18$ and $\mathrm{RP}=$ zero individuals /pond) over 6 months.

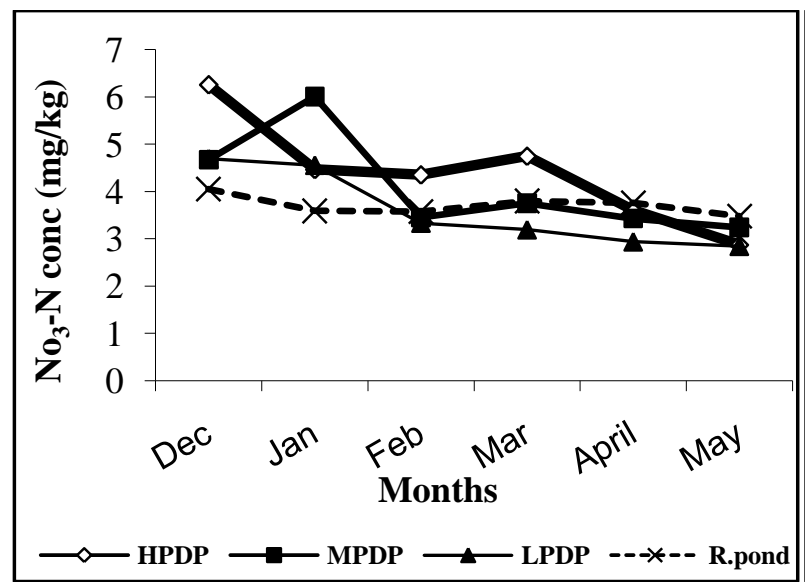

Figure 6: Average of Nitrate-N measured monthly in different population density ponds of $\mathrm{H}$. atra (i.e. $\mathrm{HPDP}=108, \mathrm{MPDP}=54, \mathrm{LPDP}=18$ and $\mathrm{RP}=$ zero individuals /pond) over 6 months.

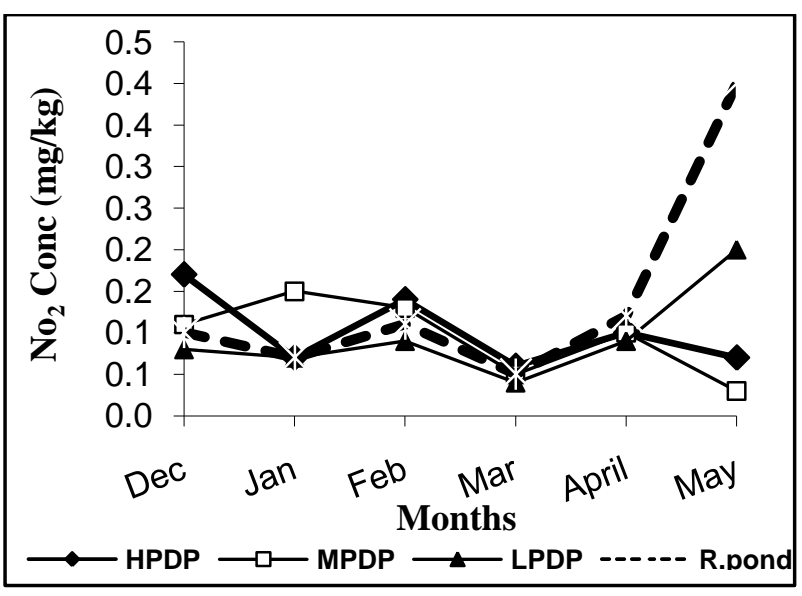

Figure 7: Average of Nitrite-N measured monthly in different population density ponds of $H$. atra (i.e. $\mathrm{HPDP}=108, \mathrm{MPDP}=54, \mathrm{LPDP}=18$ and $\mathrm{RP}=$ zero individuals /pond) over 6 months.

The maximum monthly mean of ammonia $6.93 \mu \mathrm{gg}^{-1}$ in HPDP in January and the lowest mean $0.09 \mu \mathrm{g} \mathrm{g}^{-1}$ is recorded in LPDP in March. Ammonia concentration in the ponds of H. atra was significantly low compared with the RP (Table 1; Figure 5). The highest concentration of nitrates reached $6.25 \mu \mathrm{g} \mathrm{g}^{-1}$ in the MPDP in January while the lowest monthly was $2.84 \mu_{\mathrm{g} \mathrm{g}}{ }^{-1}$ in the LPDP in March. The recorded concentrations of nitrates in the experimental ponds were lower than concentration in RP through the period of experiment (Table 1; Figure 6).

The recorded nitrite concentrations in the experimental ponds were inconsistent (Table 1; Figure 7), the highest mean of nitrite concentration $\left(0.04 \mu \mathrm{g} \mathrm{g}^{-1}\right)$ was recorded in RP in April meanwhile the lowest mean $\left(0.03 \mu \mathrm{g} \mathrm{g}^{-1}\right)$ was observed in MPDP in April. 
Table 2: Average count of Ammonifying Bacteria; Ammonium Oxidizing Bacteria; Nitrite oxidizing bacteria; amonification rate and Nitrification rate in sediment of different population density ponds and the gut contents of $H$. atra

\begin{tabular}{lccccc}
\hline Stations & $\begin{array}{c}\text { Ammonifying } \\
\text { Bacteria } \\
\left(\mathrm{MPN} \mathrm{g}^{-1}\right)\end{array}$ & $\begin{array}{c}\mathrm{NH}_{3}-\mathrm{N} \\
\text { Oxidizing } \\
\text { Bacteria } \\
\left(\mathrm{MPN} \mathrm{g}^{-1}\right)\end{array}$ & $\begin{array}{c}\text { NO-N } \\
\text { Oxidizing } \\
\text { Bacteria } \\
\left(\mathrm{MPNg}^{-1}\right)\end{array}$ & $\begin{array}{c}\text { Ammonification rate } \\
\left(\mu \mathrm{g} \mathrm{N}_{3}-\mathrm{N} \mathrm{g}^{-1} \text { soil }^{-1}\right)\end{array}$ & $\begin{array}{c}\text { Nitrification rate } \\
\left(\mu \mathrm{g} \mathrm{N}_{3}-\mathrm{Ng}^{-1} \mathrm{~h}^{-1}\right)\end{array}$ \\
\hline HPDP & 313.25 & 88.85 & 45.75 & 20.94 & 0.69 \\
MPDP & 176.75 & 32.25 & 51.00 & 18.91 & 0.51 \\
LPDP & 265.00 & 130.75 & 10.88 & 15.44 & 0.42 \\
RP & 85.25 & 50.40 & 12.25 & 11.67 & 2.14 \\
Foregut & 780.00 & 350.00 & 46.00 & 22.16 & 1.87 \\
Hindgut & 305.00 & 155.00 & 19.50 & 17.94 & \\
\hline
\end{tabular}

The highest count of ammonifying bacteria was $1100 \mathrm{MPN} / \mathrm{g}$ in foregut contents in May, while the lowest Ammonifying bacterial count 31.5 MPN/g was recorded in RP in April (Table 2; Figure 8). Meanwhile the highest count of ammonium oxidizing bacterial count (Nitrosomonassp., Nitrosospira sp. andNitrosolobussp.) $460 \mathrm{MPN} / \mathrm{g}$ was observed in the foregut contents in May, while the lowest was $20 \mathrm{MPN} / \mathrm{g}$ in hindgut contents during April (Table 2; Figure 9).Nitrite oxidizing bacterial (Nitrobacterwinogradskyi) counted the highest value 64 $\mathrm{MPN} / \mathrm{g}$ in foregut contents during April and the lowest count $6.75 \mathrm{MPN} / \mathrm{g}$ was in LPDP in May (Table 2; Figure 10).

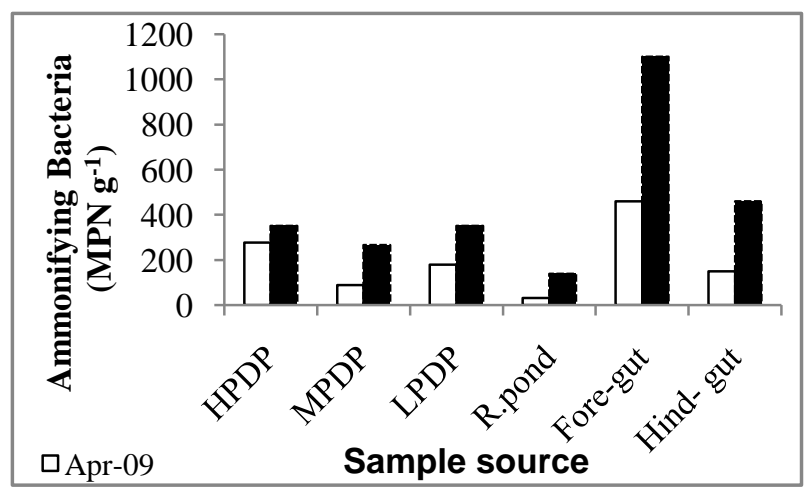

Figure 8: Variations in count of Ammonifying bacteria as MPN $\mathrm{g}^{-1}$ in sediment of different population density ponds, gut contents and skin of H. atra.

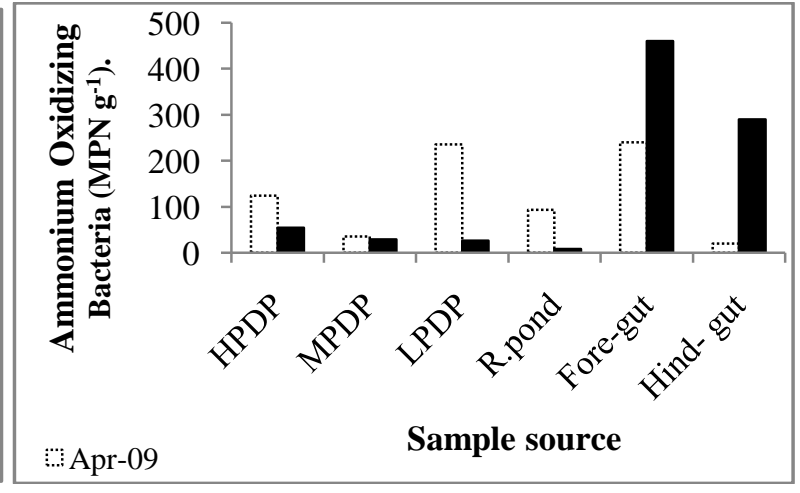

Figure 9: Variations in count of ammonium oxidizing bacteria as MPN $\mathrm{g}^{-1}$ in sediment of different population density ponds, gut contents and skin of $H$. atra. 


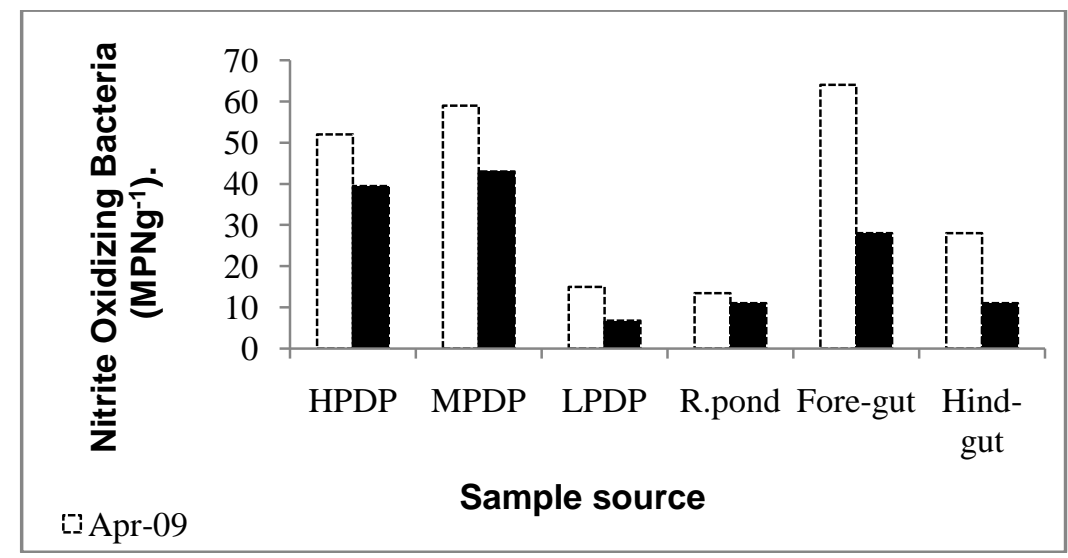

Figure 10: Variations in count of Nitrite oxidizing bacteria as MPN g-1 in sediment of different population density ponds, gut contents and skin of $H$. atra.

Table 3: Changes in average ammonification rate as $\mu \mathrm{g} / \mathrm{g} / \mathrm{h}$ in sediment of different population density ponds and the gut contents of $H$. atra.

\begin{tabular}{lcccccc}
\hline & HPDP & MPDP & LPDP & R.pond & Fore-gut & Hind- gut \\
\hline Dec. & 11.78 & 13.82 & 19.25 & 16.41 & - & - \\
Jan. & 22.16 & 17.17 & 17.25 & 12.03 & - & - \\
Feb. & 36.69 & 30.21 & 23.11 & 13.15 & - & - \\
Mar. & 22.45 & 24.14 & 11.65 & 10.20 & - & - \\
April & 16.98 & 14.98 & 10.76 & 10.85 & 23.83 & 18.43 \\
May & 15.57 & 13.14 & 10.63 & 7.38 & 20.48 & 17.44 \\
Average & 20.94 & 18.91 & 15.44 & 11.67 & 22.16 & 17.94 \\
\hline
\end{tabular}

Table 4: Changes in average Nitrification rate as $\mu \mathrm{g} / \mathrm{g} / \mathrm{h}$ in sediment of different population density ponds and the gut contents of $\mathrm{H}$. atra.

\begin{tabular}{lcccccc}
\hline & HPDP & MPDP & LPDP & R.pond & Fore-gut & Hind-gut \\
\hline Dec & 0.37 & 0.47 & 0.17 & 0.15 & - & - \\
Jan & 0.50 & 0.79 & 0.35 & 0.07 & - & - \\
Feb & 1.19 & 0.77 & 0.67 & 0.20 & - & - \\
Mar & 0.74 & 0.30 & 0.27 & 0.10 & - & - \\
April & 0.84 & 0.37 & 0.77 & 0.17 & 2.73 & 1.27 \\
May & 0.52 & 0.37 & 0.30 & 0.15 & 2.93 & 2.46 \\
Average & 0.69 & 0.51 & 0.42 & 0.14 & 2.83 & 1.87 \\
\hline
\end{tabular}

The overall means in ammonification activity values (Table 2) exhibited that the sediment of the investigated ponds with different densities of $H$. atra, RP and gut contents were varied significantly where the overall mean values of ammonification activity were $20.94 \mu \mathrm{g} / \mathrm{g} / \mathrm{h} ; 18.91$ $\mu \mathrm{g} / \mathrm{g} / \mathrm{h} ; 15.44 \mu \mathrm{g} / \mathrm{g} / \mathrm{h} ; 11.67 \mu \mathrm{g} / \mathrm{g} / \mathrm{h} ; 22.16 \mu \mathrm{g} / \mathrm{g} / \mathrm{h} ; 17.94 \mu \mathrm{g} / \mathrm{g} / \mathrm{h}$ recorded for HPDP; MPDP; LPDP; RP; Fore-gut and Hind- gut respectively in addition to the highest ammonification activity 
for the samples collected in April and May was $23.83 \mu \mathrm{g} / \mathrm{g} / \mathrm{h}$ recorded in fore-gut contents in April. Over the period of six months of study, the highest value of ammonification activity recorded was $36.69 \mu \mathrm{g} / \mathrm{g} / \mathrm{h}$ observed in HPDP in February and the lowest $7.38 \mu \mathrm{g} / \mathrm{g} / \mathrm{h}$ was observed in the RP in May. Ammonification rate in foregut content was reached $23.83 \mu \mathrm{g} / \mathrm{g} / \mathrm{h}$ in April and May declined to $20.48 \mu \mathrm{g} / \mathrm{g} / \mathrm{h}$ in May ((Table 3).

In the dry sediments, the highest activity of nitrification was $1.19 \mu \mathrm{g} / \mathrm{g} / \mathrm{hrecorded}$ in the HPDP in February while, the lowest activity was $0.07 \mu \mathrm{g} / \mathrm{g} / \mathrm{h}$ was observed in RP in January. The nitrification in foregut content showed high activities in April and May, the highest activity was in the foregut $2.93 \mu \mathrm{g} / \mathrm{g} / \mathrm{h}$ in May and the lowest was $1.27 \mu \mathrm{g} / \mathrm{g} / \mathrm{h}$ in addition to the overall means were $0.69 \mu \mathrm{g} / \mathrm{g} / \mathrm{h} ; 0.51 \mu \mathrm{g} / \mathrm{g} / \mathrm{h} ; 0.42 \mu \mathrm{g} / \mathrm{g} / \mathrm{h} ; 0.14 \mu \mathrm{g} / \mathrm{g} / \mathrm{h} ; 2.83 \mu \mathrm{g} / \mathrm{g} / \mathrm{h} ; 1.87 \mu \mathrm{g} / \mathrm{g} / \mathrm{h}$ recorded for HPDP; MPDP; LPDP; RP; Fore-gut and Hind- gut respectively (Table 2 and 4).

Data analysis showed ammonia-N; nitrate-N and nitrite- $\mathrm{N}$ concentration varied non significantly with $H$. atra population density ( $>0.05)$ while a highly significant effect recorded with Eh andNitrification activity $(\mathrm{p}<0.002)$ and significant effect onTOMand ammonification rate $(\mathrm{p}<0.05)$. This study emphasizesthe ecological role of the most dominant holothurians species, H. atra, especially in relation to organic matter assimilation, through its associated bacteria that enhance ammonification and nitrification processes in sediment.

\section{5- Discussion.}

Oxidation-reduction potential hereafter referred to as redox potential, can be used as an indicator of the degree of oxidation of sediments. Submerged sediments display a range of redox potentials from $+700 \mathrm{mV}$, which indicates highly oxidized sediment, to $-300 \mathrm{mV}$, which indicates highly reduced sediment (DeLauneet al., 1976). Intense Reduction in submerged sediments tends to buffer sediments close to $\mathrm{pH} 7.0$ (Ponnamperuma, 1972). During the current study oxidation reduction potential (Eh) increased in sediment of HPDP from $207 \mathrm{mV}$ in the beginning of the experiment to $221 \mathrm{mV}$ at the end of experiment. Slight changes recorded in Eh value in both medium and low population density ponds. While (Eh)in reference pond decreased from $191 \mathrm{mV}$ to $168 \mathrm{mV}$. In general, the present study found that Holothuriaatra density increase the redox potential of sediment and kept its characteristics in the oxidized form which enhanced the biological activities, in addition to bioturbation (Mixing) of sediment by Holothuriaatra and sediment reworking are important in establishing the sediment redox conditions and provide insight into the reactivity of sedimentary organic matter. Gordon et al., (1980) maintained that Sediment $\mathrm{pH}$ and oxidation-reduction potential were Important factors in governing the population of hydrocarbon degrading microorganisms in the sediment and subsequent mineralization rates. Highest mineralization rates occurred at $\mathrm{pH} 8.0$, and the lowest occurred at $\mathrm{pH}$ 5.0.

Results of the present study showed that OM decreased by $16.04 \%$ (22.32\% to $6.28 \%$ ); $5.34 \%$ (10.54\% to $5.2 \%) ; 3.02 \%(8.02 \%$ to $5.0 \%)$ and $3.61 \%$ (8.35\% to $4.74 \%)$ in HPDP, MPDP, LPDP and reference pond respectively. The activities of Holothuriaatra enhanced bacterial abundance, which facilitated mineralization processes and provides a mechanistic explanation for the observed reduction in sediment OM content. The low population density pond exhibited the same pattern of the reference pond. The presence of intact bacteria directly associated with the holothurians gut lining was also demonstrated by transmission electron microscopy (Deming and Colwell, 1982). Moriarty, (1982) measuredorganic carbon and nitrogen and bacterial biomass in the sediments and gut contents of Holothuriaatra and Stichopuschloronotuson the Great Barrier Reef. The author found that significantly higher values of organic carbon and nitrogen and 
muramic acid were found in foregut contents of the holothurians, indicating selective feeding on organically rich components of the sediment. Carbon values were 16-34\% higher in the foregut than in the sediment. Nitrogen values $35-111 \%$ higher and muramic acid values $33-300 \%$ higher

On the basis of these findings, the presence of an active commensal gut flora metabolizing organic matter ingested by the holothurian was suggested (Deming and Colwell, 1982). In another study, it was reported that sea cucumber prevented the formation of anaerobic conditions (Uthicke, 2001c; Kitano et al., 2003) by consuming high amount of organic matter inside the sediment. Moreover, it was observed that sea cucumber caused a reduction of ammonium level by consuming organic matter of sediment, by this way it was also able to prevent excess production of algae by stabilizing chlorophyll concentration (Moriarty, 1982).

Since there were fluctuations in ammonia, nitrate and nitrite concentrations in the present study, increase of ammonia followed by nitrate refer that there was ammonification in the sediment hosted by Holothuriaatra. Decrease of nitrite concentration may refer to nitrification process. Although, controversial results were reported for instance;Uthicke and Klumpp (1998) reported that ammonium nitrogen increased in the oligotrophic areas with sea cucumber.Uthicke (2001a) reported that there were no significant contribution on the total nitrogen in the areas of Holothuriaatra and Stichopus chloronolus. Therefore Holothuriaatra may accelerate nitrification by increasing ammonia as a result of active ammonification and could decrease ammonium concentration in sediment of the population density ponds during the present study. Webbet al., (1977) found that ammonia release rates for three species of holothurians, H. atra, H. difficilus and Actinopygamauritiana were weight specific and the release of ammonia by Holothuriaatrawas equivalent to $9 \%$ of the total ammonia exported from the reef proper.

It has been demonstrated that the holothurians and its immediate environment harbour a wide range of microorganisms. However, the presence in Holothuriaatra of a commensally gut flora, independent of that ingested in the sediment, has not been convincingly demonstrated (WardRaineyet al.,1996). The obtained results in the current study are consistent with findings ofHatmanti and Purwati (2011) who demonstrated that, there are many species of bacteria in the substrates and inside intestine of sea cucumber. There are no specificity in performance, species and number of bacteria which found in anterior or posterior of intestine, as well in their substrates. Besides that, the holothurians do not choose specific bacteria for their feed. Bacteria are the consequence of substrates ingested. Some of them can be microflora in holothurians intestine (Hatmanti and Purwati, (2011).

MacTavishet al. (2012) demonstrated that bacteria proliferated in the presence of sea cucumbers and this promoted organic matter decomposition. The average maximum value of ammonification activity and nitrification activity were $36.69 \mu \mathrm{g} \mathrm{NH}-\mathrm{N} \mathrm{g}^{-1} \mathrm{~h}^{-1}$ and1.19 $\mu \mathrm{g} \mathrm{NO}_{2}$ $\mathrm{N} \mathrm{g}^{-1}$ dry soil $\mathrm{h}^{-1}$ respectivelyrecorded for HPDP during while, the minimum values were $7.38 \mu \mathrm{g}$ $\mathrm{NH}_{4}-\mathrm{N} \mathrm{g}^{-1} \mathrm{~h}^{-1}$ and $0.07 \mu \mathrm{g} \mathrm{NO}_{2}-\mathrm{N} \mathrm{g}^{-1} \mathrm{~h}^{-1}$ recorded for reference pond. On the other hand ammonification rate and nitrification rate in foregut content is higher during the investigation period in April to May. The average of ammonification activity and nitrification activity in foregut were ranged from 20.48 to $23.83 \mu \mathrm{g} \mathrm{NH} 4-\mathrm{N} \mathrm{g}^{-1} \mathrm{~h}^{-1}$ and 2.73 to $2.93 \mu \mathrm{g} \mathrm{NO}_{2}-\mathrm{N} \mathrm{g}^{-1} \mathrm{~h}^{-1}$ respectively.

These findings supported by the obtained results of ammonifying bacteria, ammonium oxidizing bacteria and nitrite oxidizing bacterial count in foregut content were the highest during the period of studywhen compared the same parameters to that recorded in sediment of different population density ponds, reference pond hindgut and skin in addition to ANOVA two way showed Ammonification rate and nitrification rate were varied significally $(\mathrm{P}<0.01$. in different 
population density ponds of Holothuriaatra.MacTavishet al. (2012) demonstrated that bacteria proliferated in the presence of sea cucumbers and this promoted organic matter decomposition. by facilitating bacterial abundance and suppressing microphytobenthos, deposit-feeding sea cucumbers shift the microbial balance in organically enriched marine sediments and redistribute dissolved nutrients from the sediments into the pelagic environment. Moriarty (1982) indicated that bacteria and nitrogenous components of the organic matter were selectively eaten according to his findings that maintained that, Values for organic carbon and nitrogen and muramic acid were generally lower in the hindgut than in the foregut, due to digestion and assimilation. Assimilation efficiencies averaged 30\% for organic carbon, $40 \%$ for organic nitrogen and 30$40 \%$ for muramic acid (bacteria). Detritus (non-living matter) probably constituted $60-80 \%$ of the organic matter in the sediment and thus the food of the holothurians.

Observing reduction in concentrations of ammonium,nitrate, nitrite, organic matter and accelerating ammonification and nitrification rate with preventing anaerobic conditions in the sediment by Holothuriaatra.it can be concluded that Holothuriaatra can be used successfully for improvement of coastal regions with its associated fauna and flora especially coral reef. In another words, Holothuriaatra may both remove biological pollution and improve water quality in such areas. It is crucial to develop as many biological/ecological studies as possible in order to test and apply effective management measures that avoid overexploitation of this, or other, sea cucumber species (Moriarty, 1982).

\section{References.}

Ahmed, M.I. and Lawrence, A.J. The Status of Commercial Sea Cucumbers from the northern Red Sea Coast of Egypt. Beche-de-Mer Information Bulletin, 26: 14-18 (2007).

Alef, K. and Kleiner.Arginine Ammonification, a simple method to estimate microbial activity potentials in soils. Soil Biol. Biochem. 18: 233-235(1986).

Alexander, M. Most Probable Number method for microbial populations.In "Methods of soil analysis".Part 2. Black, C. A. et al., eds. Am. Soc. Agron. Madison. Winconsin. 39: 815820(1982).

Amon, R.M.W. and Herndl G.J. Deposit feeding and sediment II.Decomposition of fecal pellets of HolothuriatubulosaHolothuroidea Echinodermata, Mar. Ecol. 12: 175184(1991).

Barlocher, F. and Kendrick, B. Hyphomycetes as intermediaries of energy flow in streams. In, Recent advances in aquatic mycology, edited by E.B. Gareth Jones, Halsted Press, New York. 435-446 (1978).

Barnes, H., and Folkard, A.R. The determination of nitrites.Analyst (London). 76: 96603(1951).

Barnes, R.D. Invertebrate Zoology. $5^{\text {th }}$ ed. Harcourt Brace Jovanovich College Publishers, Fort Worth(1987).

Belser, L.W. and Mays, E.L. Use of nitrifier activity measurements to estimate the efficiency of viable nitrifier counts in soils and sediments. Appl. and Environ. Microbiol., 43 (4): 945948(1982). 
Bremner, J.M. Inorganic forms of nitrogen.In "Methods of soil analysis".Part 2. Black, C. A. et al., eds. Am. Soc. Agron. Madison. Winconsin. 9: 1179-1237(1965).

Bremner, J.M. and Keeney, D.R. Steam Distillation Methods for the determination of ammonium, nitrate and nitrite.Anal.Chim.Acta. 32: 485-495(1965).

Conand, C. Asexual reproduction by fission in Holothuriaatra: Variability of some parameters in populations from the tropical Indo-Pacific. OceanologicaActa. 19 (3): 209-216(1996).

Conand, C. Present status of world sea cucumber resources and utilization: an international overview: 13-23 In: Advances in sea cucumber aquaculture and management. Lovatelli A., Conand C, Purcell S., Uthicke S., Hamel J.-F. and Mercier A. (eds). FAO Fisheries Technical Paper.No. 463. Rome, FAO. 2004. 425 pp(2004).

Conand, C. Population status, fisheries and trade of sea cucumbers in Africa and the Indian Ocean. In: ToralGranda, V., Lovatelli, A. and Vasconcellos, M. (Eds.), Sea cucumbers - A global review of fisheries and trade. FAO fisheries and aquaculture technical paper, No. 516, FAO, Rome.143-193(2008).

Conand, C. and Mangion, P. Sea cucumbers on La Réunion Island fringing reefs: diversity, distribution, abundance and structure of the populations. SPC Bêche-de-Mer Information Bulletin, 17: 27-32(2002).

Dean, W.E. Determination of carbonate and organic matter in calcareous sediments and sedimentary rocks by loss of ignition: Comparison with other methods. J.Sed.Petrol. 44: $6 \mathrm{p}(1974)$.

DeLaune, R.D., Patrick, W.H. and Brannon, J.M. Nutrient transformations in Louisiana salt marsh soils. Sea Grant Publ. No.LSU-T-76-009.Center for Wetland Resources, Louisiana State Univ. Baton Rouge, La(1976).

Deming, J.W., and Colwell, R.R. Barophilic Bacteria Associated with Digestive Tracts of Abyssal Holothurians. App. and Env.Micr. 44(5): 1222-1230(1982).

Dhinakarana, I, and Liptonb, A.P. Pharmacological Potentials of Sea Cucumber HolothuriaAtra Extracts from the Indian Ocean D. Asian Journal of Biomedical and Pharmaceutical Sciences, 4 (35): 36-43(2014).

Gordon, A., Hambrick, I.I.I., Ronald, D. and Patrick, W.H. Effect of Estuarine Sediment pH and Oxidation-Reduction Potential on Microbial Hydrocarbon Degradation. Appl. and Env.Micro. 40(2): 365-369(1980).

Graham J. and Battaglene S. Periodic movement and sheltering behaviour of Actinopygamauritiana (Holothuroidae: Aspidochirotidae) in Solomon Island. SPC Bechede-mer Inform. Bull., 19: 23-31(2004).

Groffman, P.G. Nitrification and denitrification in soil: A comparison of enzyme assay, incubation and enumeration methods. Plant and soil. 97: 445-450(1987).

Hanafy, M.H. A study on the effect of the sea cucumber Actinopygamauritiana (Echinodermata: Holothuroidea) on the sediment characteristics at El-Gemsha Bay, Red Sea coast, Egypt. Int. J. of Environ. Sci and Eng. (IJESE).2: 35-44(2011).

Hatmanti, A. and Purwati, P. Bacteria associated Holothurians: The key of habitat preference, diet, and functions. J. IlmudanTeknologiKelautanTropis. 3(1): 73-81(2011). 
Heezen, B.C. and Hollister, C.D. The face of the deep.Oxford Univ. Press, New York, London, and Toronto.659 p(1971).

Hopkinson, S.C. JR. Shallow-water benthic and pelagic metabolism: evidence of heterotrophy in the near shore Georgian Bight. Marine Biology. 87: 19-32(1985).

Jaquemet, S., Rousset, V. \&Conand, C. Asexual reproduction parameters and the influence of fission on a Holothuriaatra sea cucumber population from a fringing reef on Réunion Island (Indian Ocean). Bêche-de-Mer Information Bulletin, 11: 12-18(1999).

Kinch, J. An Overview of the Beche-de-mer Fishery in the Milne Bay Province, Papua New Guinea(2002).

Kitano, M., Kurata, K., Kozuki, Y., Murakami, H., Yamasaki, T., Yoshida, H. and Sasayama, H. Effects of deposit feeder Stichopus japonicas on algal bloom and organic matter contents of bottom sediments of the Enclosed Sea, Mar.Pollution Bul. 47: 118125(2003).

Laubier, L. and Sibuet, M. Ecology of the benthic communities of the deep North East Atlantic. Ambio Special Report 6:37-42(1979).

Lawrence, A.J., Ahmed, M., Hanafy, M., Gabr, H., Ibrahim, A. \& Gab-Alla, A.A. Status of the sea cucumber fishery in the Red Sea - the Egyptian experience. pp. 79-90. In: Advances in sea cucumber aquaculture and management. Lovatelli A., Conand C, Purcell S., Uthicke S., Hamel J.-F. and Mercier A. (eds.). FAO Fisheries Technical Paper.No. 463. Rome, FAO. 2004. 425p(2004).

MacTavish, T., Stenton-Dozey, J., Vopel, K, and Savage, C. Deposit-Feeding Sea Cucumbers Enhance Mineralization and Nutrient Cycling in Organically Enriched Coastal Sediments. PLoS ONE. 7(11): e50031. doi:10.1371/journal.pone.0050031(2012).

Mangion, P., Taddei, D., Frouin, P. and Conand, C. Feeding rate and impact of sediment reworking by two deposit feeders Holothurialeucospilota and Holothuriaatra on a fringing reef (Réunion Island, Indian). In: Echinoderms: München. Heinzeller and Nebelsick (eds.), Taylor and Francis, London: 311-317 (2004).

Menzies, R.H., George, R.Y., Rowe, G.T.Abyssal environment and ecology of the world oceans Wi.leyInterscience, New York(1973).

Moriarity, D.J.W. Feeding of Holothuriaatra and Stichopuschloronotus on bacteria, organic carbon and organic nitrogen in sediments of the Great Barrier Reef. Aust. J. Mar. Freshwat. Res. 33: 255-263(1982).

Nancy, I.L., Carlos, M.D., Vallespinos, F., Romero, J. and Alcoverro, T. Bacterial activity in NW Mediterranean seagrass (Posidonia oceanica) sediments.J. of Experi. Mar. Biol. and Ecol., 187: 39-49(1995).

Phillips, N.W. Role of different microbes and substrates as potential suppliers of specific essential nutrients to marine detritivores, Bull. Mar. Sci.: 35: 283-298(1984).

Ponnamperuma, F.N. The chemistry of submerged soils. Adv. Agron. 24: 29-88(1972).

Purcell, S.W., Gossuin, H. and Agudo, N.S. Status and management of the sea cucumber fishery of La Grande Terre, New Caledonia. World Fish Center studies and reviews No.1901. The World Fish Centre, Penang, Malaysia.136 pp(2009). 
Purser, D.B. Nitrogen metabolism in the rumen: microorganisms as a source of protein for the ruminant animal, J. Anim. Sci. 30: 988-1001(1970).

Asha, P.S., Diwakar, K., Santhanavalli, G.and Mary, Manissery, K. Comparative distribution and habitat preference of the sea cucumber Holothuriaatra Jaeger at protected and unprotected sites in Thoothukudi region of Gulf of Mannar, south-east coast of India.Indian J. Fish., 62 (1): 52-57, 2015 52(2015).

Santos, V., Billett, D.S.M., Rice, A.L., Wolff, G. A. Organic matter in deep-sea sediments from the porcupine abyssal plain in the north-east Atlantic Ocean: 1. Lipids. Deep-Sea Res. 41:789-819(1994).

Schmidt, E.L. and Belser, L.W. Nitrifying bacteria.In Methods of soil analysis.Part 2. Black, C.A. et al., eds. Amon. Soc. Agron. Madison. Winconsin.1027-1041 (1982).

Skillings, D.J., Bird, C.E and Toonen, R.J. Gateways to Hawai' I : Genetic Population Structure of the Tropical Sea Cucumber Holothuriaatra. Hindawi Publishing Corporation, Journal of Marine Biology. 2011: 1-16(2011).

Sloan, N.A. and Von Bodungen, B. Distribution and feeding of the sea cucumber Isostichopus badionotus in relation to shelter and sediment criteria of the Bermuda platform. Marine Ecology Progress Series. 2: 257-264(1980).

Taddei, D. Matter and energy transfers in soft-bottom sediments of an anthropogenic reef complex (La Réunion Island, Indian Ocean). Ph.D. Thesis, La Réunion University,(2006).

Uthicke, S. Nutrient regeneration by abundant coral reef holothurians. J. of Exp. Mar. Biol. and Ecol., 265:153-170(2001a).

Uthicke, S.The influence of asexual reproduction on the structure and dynamics of Holothuria (Halodeima) atra and Stichopuschloronotus populations of the Barrier Reef. J Mar Freshwater Res., 52: 205-215(2001b).

Uthicke, S. Interactions between sediment-feeders and microalgae on coral reefs: Grazing losses versus production enhancement. Mar. Ecol. Prog. Ser. 210: 125-138(2001c).

Uthicke, S. and Klumpp, D.W. Microbenthos community production in sediments of a near shore coral reef: seasonal variation and response to ammonium recycled by holothurians. Mar. Ecol. Prog. Ser., 169: 1-11(1998).

Vine, P. Red Sea invertebrates.Immel publishing, London.224p(1986).

Wainwright, S.C. sediment-to-water fluxes of particulate material and microbes by suspension and their contribution to the planktonic food web.Marine Ecology Progress Series. 62: 271281 (1990).

Ward-Rainey, N., Fred, A., Rainey and Erko, S. A study of the bacterial flora associated with Holothuriaatra. J. of Exp. Mar. Biol. and Ecol. 203: 11-26(1996).

Webb, K.L., Du Paul, W.D. and D'elia, C.F. Biomass and nutrient flux measurements on Holothuriaatra populations on windward reef flats at Eniwetok, Marshall Islands. Third International Coral Reef. Miami, Florida. Rosenstiel School of Marine an. D.L. Taylor. 1: 409-416 (1977). 


\title{
الملخص باللغة العربية
}

\section{تأثير خيار البحر من نوع هولوثُوريا اترا على تمثيل المواد العضويهـ معل انتاج الامونيا ومعدل النيترة

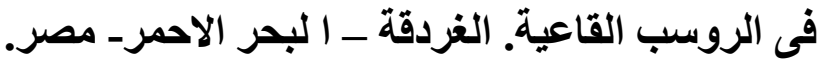

المتولى السحات شبانة المتولى 1 ،وليدمحدالقزاز 2، محمودعبدالراضدار 33، أحمدويدارعبد هالبسيونى 4

\author{
1- 2- جهاز شئون البيئة ـ الفر ع الاقليمى لمنطقة البحر الاحمر.

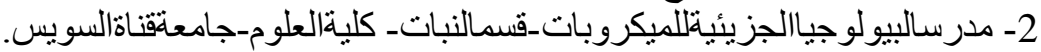

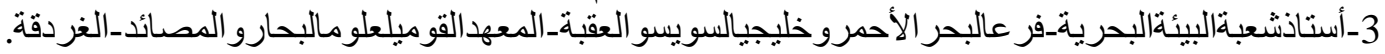

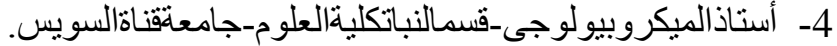

أجريت الدراسة لبحث تاثير الكثافة العددية لخيار البحر عل خصائص التربه القاعبه ومن العو امل التى تم دراستها،

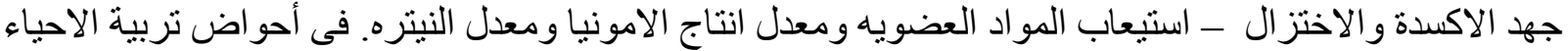

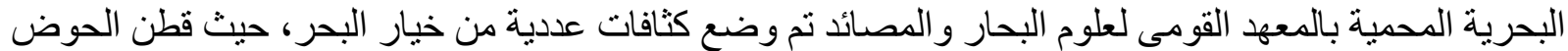

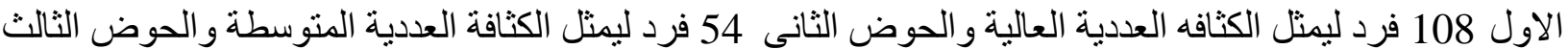

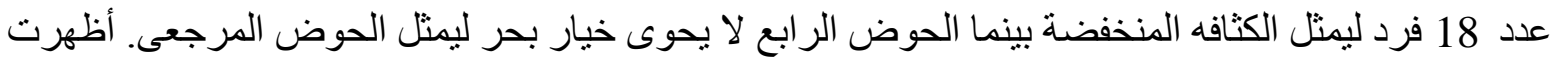

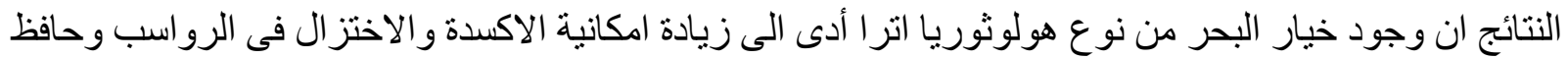

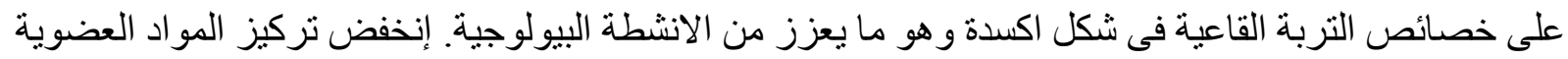

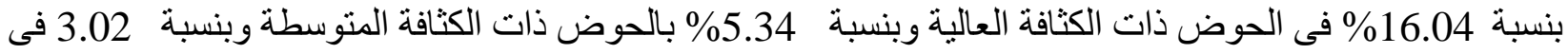

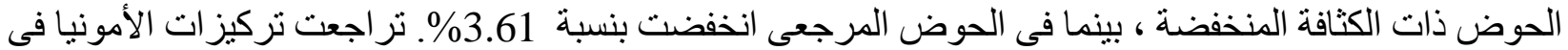

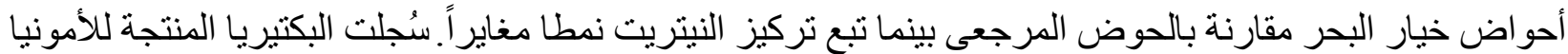

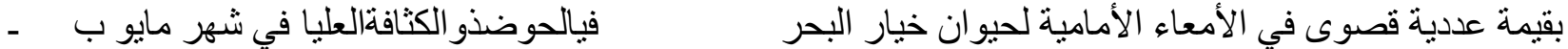
1100 MPN g ${ }^{-1}$

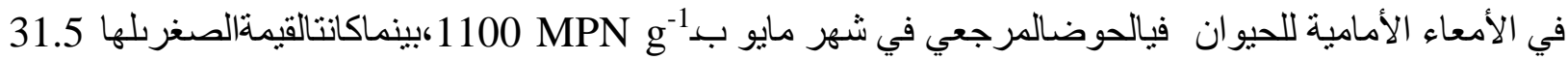

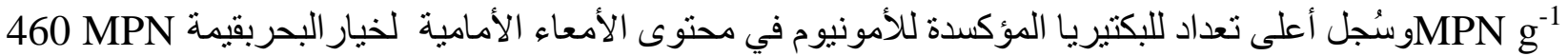

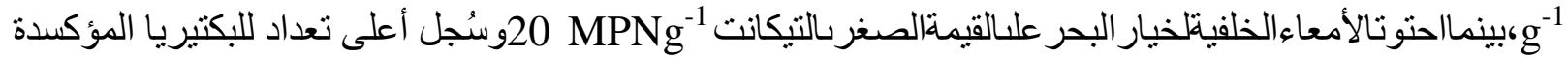
64 MPN gقيمة اللنيتريت في محتوى الأمعاء الأمامية

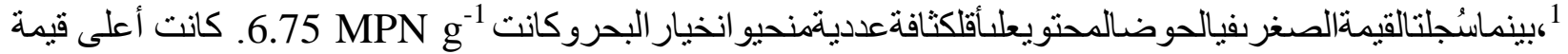

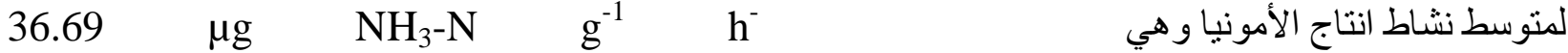

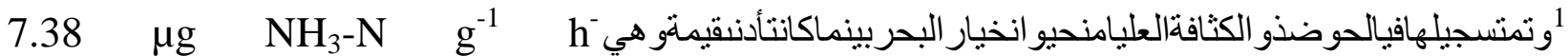

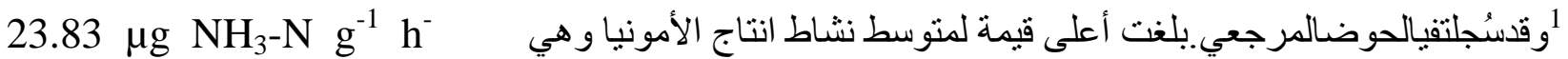

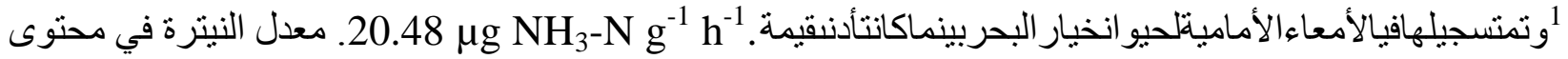
الأمعاء الأمامية لخيار البحر هو الأعلى أثناء فترة الدراسة، حيث بلغت القيمة القصوى لمتوسط معدل النيترة 2.93

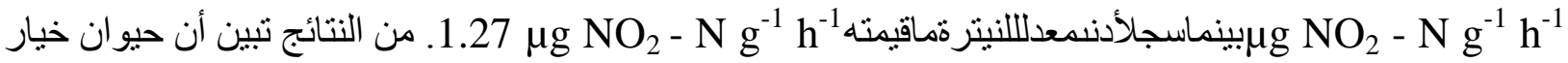

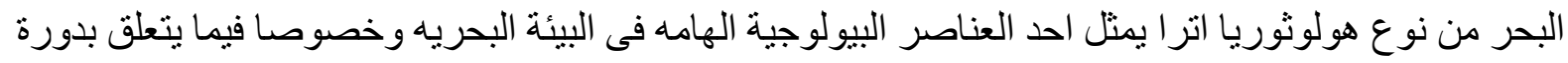

